\title{
'Saved from the sordid axe': representation and understanding of pine trees by English visitors to Italy in the eighteenth and nineteenth century
}

Pietro Piana, Charles Watkins and Ross Balzaretti

\begin{abstract}
Pine trees were frequently depicted and celebrated by nineteenth century English artists and travellers in Italy. The amateur artist and connoisseur Sir George Beaumont was horrified to discover in 1821 that many Roman stone pines were being felled and paid a landowner to preserve a prominent tree on Monte Mario. William Wordsworth saw this tree in 1837 and celebrated that it had been 'Saved from the sordid axe by Beaumont's care'. Pines continued to be painted by amateurs and professionals including Elizabeth Fanshawe, William Strangways, Edward Lear, John Ruskin. These trees were also an important element of local agriculture; in parts of Liguria they were grown in vineyards in an unusual type of coltura promiscua providing both support for the vines and fertiliser from pine needles; in Tuscany and Ravenna pine plantations and forests were an important source of pine nuts. In this paper we combine the analysis of local land management records, paintings and traveller's accounts to reclaim differing understandings of the role of the pine in nineteenth century Italy.
\end{abstract}

\section{Introduction: Sir George Beaumont, Wordsworth and the pines of Rome}

With the final defeat of Napoleon at Waterloo in June 1815 Italy, especially Rome, once again became a favourite destination for British cultural tourists (Buzard, 1993, Liversidge and Edwards, 1996, Black, 2003, Brilli, 2006, Piana, et al 2012). The poet Catherine Maria Fanshawe, writing from Rome 11 January 1820 to her friend Lady Bury in London 
emphasised her delight at being able to experience ancient and modern Rome: 'Not all the preparation of traversing Sea and Land and Mountains and Vallies quite accounts for the fact of being actually at Rome and though I know it when I lie down at night I am hardly less amazed when I rewake to see the Pillar of Trajan before my window.' She was disappointed to report that she had missed her friend the artist Sir Thomas Lawrence, President of the Royal Academy by only 4 days, and was concerned that 'there is still here a swarm of English: not a very interesting set in general'. However on 'the very night of my arrival I visited the Coliseum by moonlight and the next was shown the finest statues in the Vatican by torchlight, a treat indeed.' St Peter's 'afforded me the noblest pleasure' she felt she 'were beholding in Heaven the work not of angels but of beatified spirits decked in all the glory and magnificence of a celestial church. ${ }^{1}$

The friends she met in Rome included Sir George and Lady Beaumont who were in Rome 1819-22. Sir George (1753-1827) was one of the leading connoisseurs, amateur artists and art collectors of the late eighteenth and early nineteenth centuries. His wealth was derived largely from his estates at Coleorton, (Leicestershire) and Dunmow (Essex) and his collection included works by Rubens, Rembrandt, Claude and Poussin, some of which he had purchased on his first visit to Rome 1782-3. He was a leading patron of John Constable and he gave his collection during his lifetime to help establish the National Gallery (Owen et al 1988). The Beaumonts had a wide circle of literary friends including Coleridge and William Wordsworth. While in Rome the Beaumonts were introduced to Charles Eastlake, later director of the National Gallery, by Catherine Fanshawe, and also met regularly the leading sculptor Antonio Canova who helped Sir George to purchase the outstanding sculpture 'Virgin and

\footnotetext{
${ }^{1}$ Catherine Maria Fanshawe to Catherine M Bury, the Countess of Charleville, Roma 11 January 1820, Manuscripts and Special Collections, University of Nottingham [My 269]
} 
Child with St John' by Michelangelo, now at the Royal Academy (Owen and Brown 1988, Avery-Quash and Sheldon 2011).

Sir George made excursions into the countryside with the poet Samuel Rogers, including one to Frascati 'through galleries or avenues of ilex and cypress' taking in views of Rome and the Campagna (Owen and Brown 1988, p. 204). He particularly admired the stone pine trees of Rome and later told his friend Wordsworth that on his first visit in the 1780s 'pinetrees of this species abounded, but that on his return thither, which was more than thirty years after, they had disappeared from many places where he had been accustomed to admire them, and had become rare all over the country, especially in and about Rome' (Knight 1896, pp. 58-9). Wordsworth visited Rome in 1837 travelling with Henry Crabb Robinson (Sadler 1869). Writing to his sister Dorothy in April 1837 he noted that 'we had scarcely been two hours in Rome when we walked up to the Pincian hill, near our hotel. The sun was just set, but the western sky glowed beautifully.' The 'modern' part of Rome was below them 'and St. Peter's rose on the opposite side'. He noted 'for dear Sir George Beaumont's sake' that 'at no great distance from the dome of the church on the line of the glowing horizon was seen one of those broadtopped pines, looking like a little cloud in the sky, with a slender stalk to connect it with its native earth.' The English sculptor William Theed, who worked in Rome 'accosted' Robinson by name and told them that the tree which Wordsworth 'admired so much had been paid for by our dear friend' upon the condition 'that the proprietor should not act upon his known intention of cutting it down' so that 'it might stand as long as nature might allow (Robinson 1869, pp. 116-7, Knight 1896, pp. 58-9). ${ }^{2}$

A week later Wordsworth told his wife and sister that 'The Monte Mario commands the most magnificent view of modern Rome, the Tiber, and the surrounding country.' He climbed the hill and 'I stood under the pine, redeemed by Sir G. Beaumont, of which I spoke in my former letter. I

\footnotetext{
${ }^{2}$ Letter of William Wordsworth to Dorothy Wordsworth (April 27, 1837)
} 
touched the bark of the magnificent tree, and I could almost have kissed it out of love for his memory. ${ }^{\prime 3}$ He later embellished the story stating that 'having ascended the Monte Mario, I could not resist embracing the trunk of this interesting monument of my departed friend's feelings for the beauties of nature, and the power of that art which he loved so much, and in the practice of which he was so distinguished' (Knight, 1896 pp. 58-9). The chance discovery of Sir George's pine tree was recounted by Wordsworth in his sonnet 'The Pine of Monte Mario at Rome' written at the time:

I saw far off the dark top of a Pine

Look like a cloud-a slender stem the tie

That bound it to its native earth-poised high

'Mid evening hues, along the horizon line,

Striving in peace each other to outshine.

But when I learned the Tree was living there,

Saved from the sordid axe by Beaumont's care,

Oh, what a gush of tenderness was mine!

The rescued Pine-tree, with its sky so bright

And cloud-like beauty, rich in thoughts of home,

Death-parted friends, and days too swift in flight,

Supplanted the whole majesty of Rome

(Then first apparent from the Pincian Height)

Crowned with St. Peter's everlasting Dome.

\footnotetext{
${ }^{3}$ Letter of William Wordsworth to Mary and Dorothy Wordsworth (May 6, 1837)
} 
The sonnet reinforced the importance of the pines of Rome for literary British visitors. Sir George's action in saving a single tree appeared to have influenced others to conserve the Roman pine trees. Wordsworth noted that several Roman villas had in recent years 'passed into the hands of foreigners' who he noticed had 'taken care to plant this tree, which in course of years will become a great ornament to the city and to the general landscape' (Knight, 1896 pp. 58-9). Sir George Beaumont's action in saving a single, prominent pine which was a crucial part of a well-known landscape view is a very early example of practical landscape preservation. But it also allows us to explore the complicated relationship been artists and the trees and landscapes they painted.

There is now a long and well established tradition of historical and cultural geographers and landscape historians using art as a way of understanding past landscapes (Landscape and topographical art if placed in a historical and cultural context, can provide important insights into the way that land is managed and understood (Berger, 1972, Barrell 1980, Cosgrove and Daniels 1988, Piana et al 2012). The importance of trees within landscape history, and the changing relationship between humans and trees, has received considerable attention in recent years (Hooke, 2010; Watkins, 2014) but there has been relatively little work on the value of representations of individual species. This paper examines how British visitors gained knowledge of Italian trees through drawings, paintings and prints, before and during their visits to Italy. The paper considers knowledge of pines by late eighteenth and early nineteenth century authorities such as William Gilpin and John Claudius Loudon. It then focuses on the representation and understating of pines in three contrasting sites: the pines of Rome, the coastal pines of Liguria and finally the famous pine wood of Ravenna. 


\section{Italian pines}

The identification and classification of Mediterranean pine trees has long been problematic but recent advances in genetic analyses have helped to clarify the origin and distribution of different species in Europe (Kirby and Watkins 2015). There are eleven species of pine in the Mediterranean Basin (Fady 2012). Three of these, Pinus halepensis (Aleppo pine), Pinus pinaster (maritime pine) and Pinus pinea (stone pine), grow well in coastal situations and are the main species discussed in this paper.

Sir George Beaumont's favourite tree was a stone pine (Pinus pinea) which is widespread across Mediterranean Europe from Spain through to Lebanon. Vendramin et al. (2007) carried out genetic analysis of 34 populations of Pinus pinea and found that it was 'truly exceptional among widespread, sexually reproducing plant species for its low level of genetic diversity'. A possible explanation is that at some stage in its history the species suffered a wide-ranging decline and became limited to a single, geographically-circumscribed population. This prolonged demographic bottleneck may have been exacerbated by their seed dispersal mechanism, which contrary to most pines, is dependent on mammals and birds rather than wind dispersal. The 'scarcity of seed dispersers during critical periods of the species history' may then have reduced the ability of the tree to move to new territories and made it 'more susceptible to range contractions' eventually influencing its genetic diversity.

From around 3000 years ago when humans started to plant and cultivate the tree because of the value of its pine nuts the species became widely spread throughout the Mediterranean. The survival and distribution of the stone pine became inextricability linked with human settlement and cultivation. Puglisi et al. (2000) examined the genetic structure of nine 'natural' populations of this pine growing in Apulia, Calabria and Basilicata. They combined this analysis with charcoal data from archaeological sites and concluded that there was a strong possibility that 
these populations of trees could have been introduced by Greek colonists to southern Italy. The importance of the seeds of pine in commerce is confirmed by research on the persistence of the cultural landscape in Campania before the 472 AD Vesuvius eruption which found that pine cones and scales were 'the most frequent fruit in the Neapolis' harbour sediments (1st c. BC - 5th c. AD) testifying also its trade and the wide use of this fruit.' (Allevatoa et al 2012, p. 404). Martínez and Montero (2004) contrast the certain evidence that the stone pine 'is an autochthonous species to the Iberian Peninsula' with the conflicting evidence about whether the stone pine is native to Italy (Agrimi and Ciancio 1994).

Modern questioning of the 'naturalness' of stone pines is reflected in the classical authorities. Theophrastus noted that people distinguished between 'the wild and the cultivated kinds' and described the stone pine as a cultivated tree. (Hort 1916, Vol 2, p. 211 [Theophrastus, 3.9.1]) Pliny describes 'the largest fruit and the one that hangs highest is that of pine-cones' and identifies four types of pine kernels (Rackham 1945, Vol 4, p. 313 [Pliny, Book XV, IX]). These authorities were often referred to by English writers on trees in the eighteenth and nineteenth centuries and provided a basis of knowledge for travellers.

William Gilpin (1724-1804) whose picturesque tours were influential in the late eighteenth century described trees from the perspective of an artist in his Remarks on Forestry Scenery of 1791 . He noted that young stone pines promised little 'in terms of picturesque beauty' but that as they matured their 'picturesque form increases fast' and praised the 'easy sweep' of the pine's 'lengthening stem' a 'gentle deviation' which was 'very graceful; and above all other lines difficult' for the artist to imitate. He noted that the foliage of the stone pine 'instead of breaking into acute angles, like many of the pine-race, is moulded into a flowing line by an assemblage of small masses.' He considered that one of the 'beauties of the stone-pine' was 'that as the lateral branches decay, they leave 
generally stumps, which standing out in various parts of the stem' broke the continuity of its lines. Gilpin recognised that the stone pine was 'not indigenous to our soil, but like the cedar, it is in some degree naturalized; tho in England it is rarely more than a puny, half formed resemblance of the Italian pine.' Indeed he felt that 'The soft clime of Italy alone gives birth to the true picturesque pine. There it always suggests ideas of broken porticos, Ionic pillars, triumphal arches, fragments of old temples, and a variety of classic ruins, which in Italian landscape it commonly adorns.' An early nineteenth century editor of Gilpin confirmed that the stone pine 'is quite associated in our minds with Italy, and her magnificent remains.' (Gilpin 1791, pp. 79-80; Lauder, 1834, I p. 169.)

Notwithstanding Gilpin's praise of the stone pine, the great nineteenth century arboriculturalist John Claudius Loudon thought it unlikely that he had ever seen a living tree. The stone pine had probably been introduced to England in the mid sixteenth century and Loudon noted that 'as the seeds are easily procured from Italy, it had been frequently planted in collections.' However, because of its susceptibility to frosts and slow growth it 'has been generally choked by other trees, so that good specimens are rarely to be met with in English plantations.' Loudon thought Gilpin, who had never travelled in Italy, must be alluding 'chiefly to what he had seen in prints or pictures.' Alternately, he wondered whether Gilpin may have mistaken the Pinus pinaster, which grew quite well in Britain, with the Pinus pinea and noted that this confusion remained in the nineteenth century as from 'specimens and dimensions that have been sent to us from different parts of the country, we find that the pinaster is very frequently supposed to be the stone pine. Indeed it may be considered as the stone pine of Britain.' (Loudon $1854 \mathrm{~V} 2228$ 2230)

The uncertainty over the identification and distribution of the stone pine remained in the early twentieth century. Elwes and Henry (1906-13 5 pp 1120-2) point out that while it is 'native of the Mediterranean region' it 
'has been extensively planted for centuries, and it is difficult to ascertain whether existing woods are natural or artificial in many localities.' They consider it be 'wild at intervals on the west coast, from Genoa, where it occurs on the low hills, to Ostia, mainly growing on sandy plains in mixture with P. Pinaster.' Most visitors to Italy will not have been particularly interested in the naturalness and precise identity of pines; they did however, relish exotic and foreign trees, such as pines and cypresses, which to them became closely associated and emblematic of the Italian travels.

\section{Drawing Roman pines: Claude and his influence on British artists}

Sir George Beaumont's education and travels are of significance in understanding his fascination with landscape painting and his love of pines. He was taught drawing at Eton in the 1740 s by the artist Alexander Cozens and also knew the artist Richard Wilson. Both these artists had spent several years in Rome and influenced the way he understood landscape. Beaumont's fascination with Claude was encouraged by his first visit to Rome in the early 1780 s and he became 'one of the most enthusiastic and influential of all English admirers' of the artist (National Gallery 1988, p. 19). Claude Lorrain (Claude Gellée, le Lorrain) was born near Nancy around 1600 and lived permanently in Rome from 1627. His landscape painting had an enormous influence on English landscape painting from the mid eighteenth century and 'British collectors acquired so many works by Claude that it is no exaggeration to say that nearly all his paintings, drawings, and - to a lesser extent - prints have been in British collections'(Sonnabend and Whiteley 2011, p. 17). Marcel Roethlisberger (1968) uses a comparison of two drawings of the same clump of pine trees to argue convincingly that Claude closely observed nature and that he drew 'on the spot' (Plates 1 and 2: Roethlisberger 6; 111 , p. 112). These two drawings were in the large collections of Claude drawings left to the British Museum in 1824 by the collector and connoisseur Richard Payne Knight. Another pen and ink drawing 
'Landscape; a grove of pine trees, towards a hill with two ruined towers' c.1638-9 (Plate 3) depicts the fortified walls of Civitavecchia on the coast near Rome with trees in the foreground and the beach and sea behind. The drawing has been celebrated for Claude's penwork which 'tended to be extremely fine, particularly when he depicted pine groves.' (British Museum Curator's comments for Oo,7.230; Roethlisberger, 1968, 395). These pines do not appear to be stone pines: the straight form of the tree trunks in this drawing are more like the maritime or Aleppo pine, which grow on the coast. By contrast, his drawing of a pine tree c 1665 with two figures standing beneath (Plate 4; Oo,7.179; Roethlisberge, 1968, 903) shows the characteristic shape of a maturing stone pine tree and the type 'dominating noble pine trees that occur frequently in his later oil paintings (Roethlisberger 1968, p. 337). These drawings show not only that Claude drew from nature but that he was able to represent convincingly the shape and form of different species of pine tree.

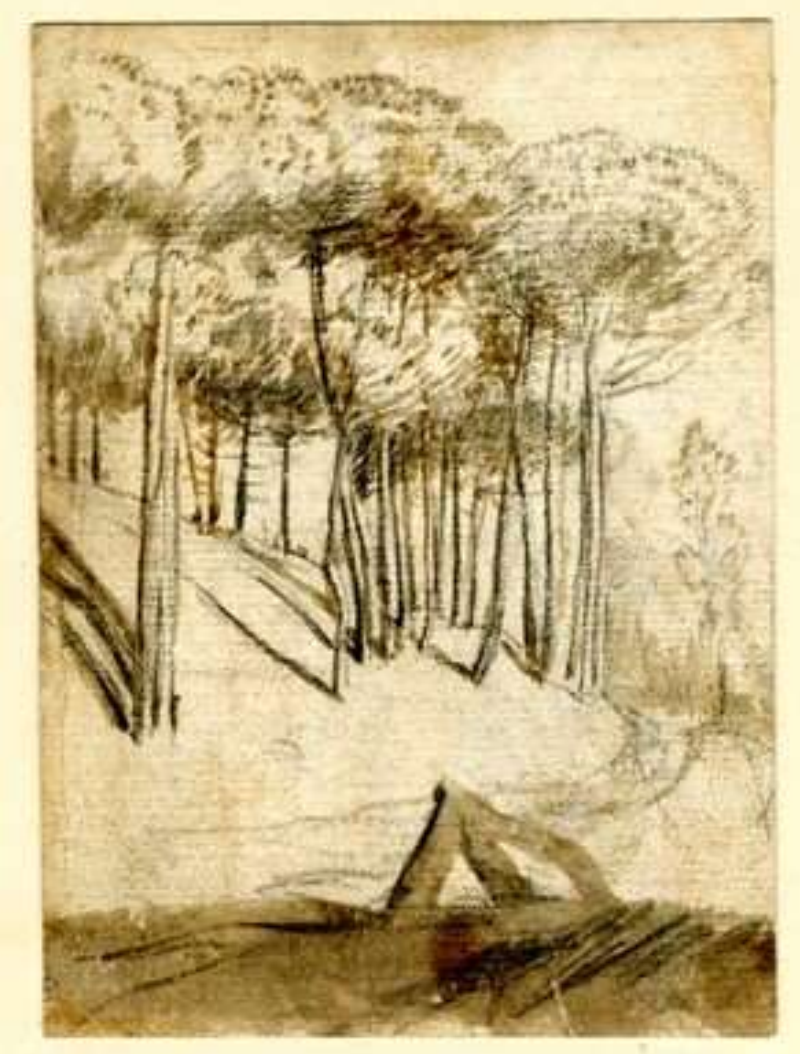

Plate 1 Roethlisberger 6 (British Museum) 


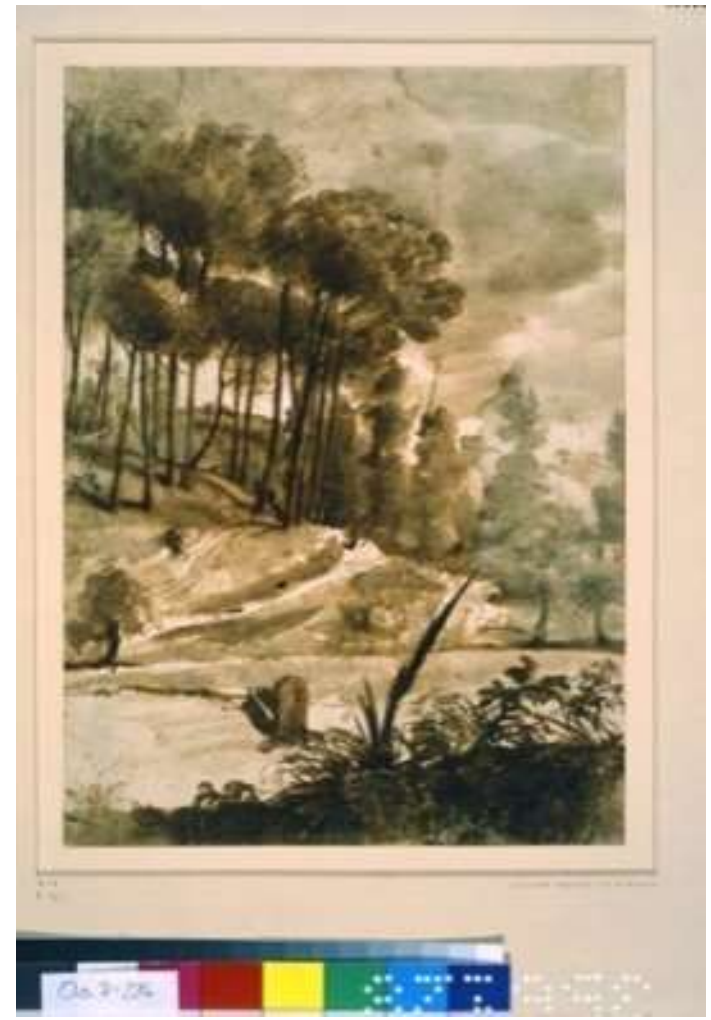

Plate 2 Roethlisberger 6 (British Museum)

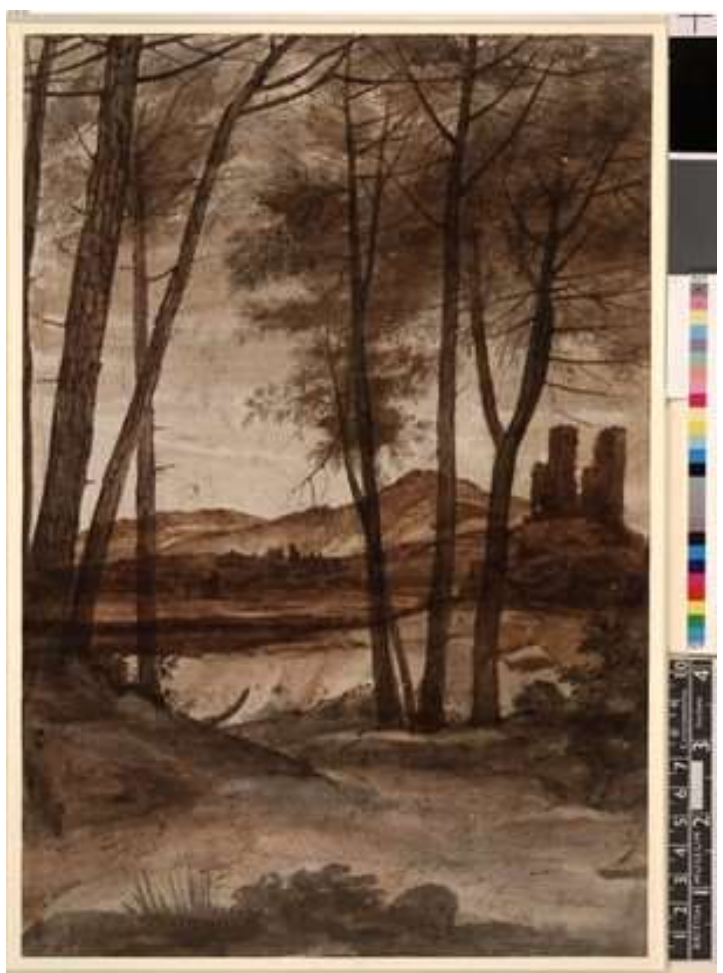

Plate 3 Roethlisberger 395 (British Museum) 


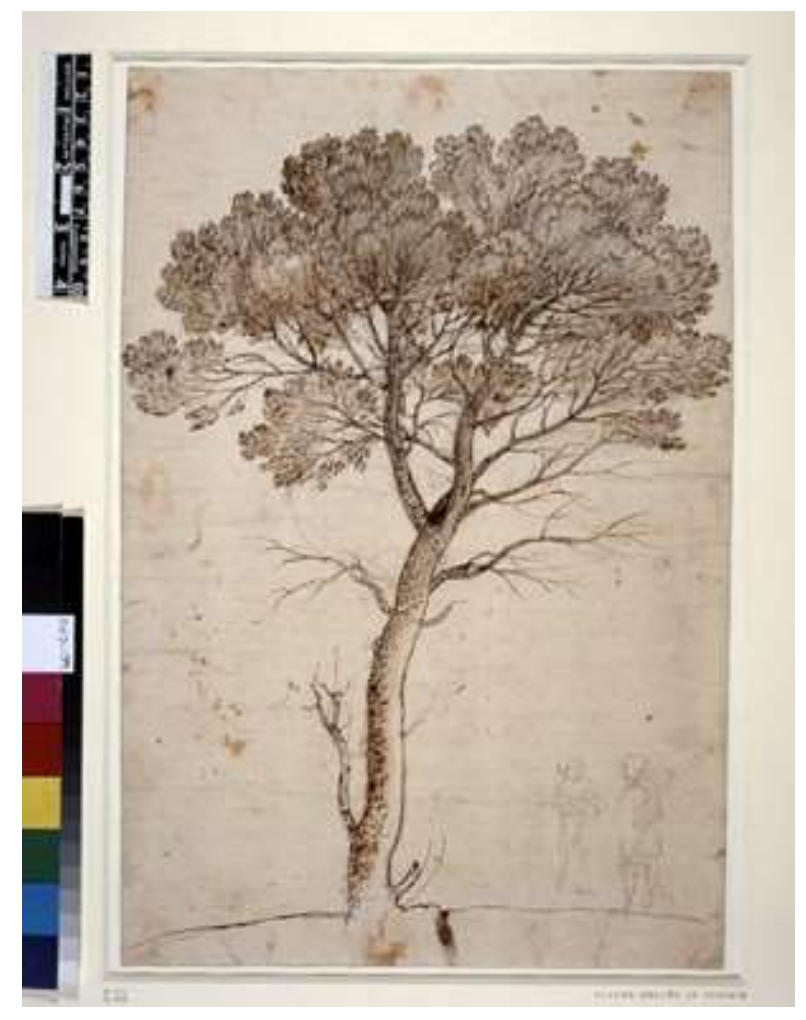

Plate 4 Roethlisberger 903 (British Museum)

There is no proof that Claude painted 'en plein air' though there is little doubt that 'he sketched in nature with the intention of capturing the ephemeral effects of reality.' But Claude's landscapes were 'inventions' or 'constructions' and 'faithful representations of real places' were an exception (Sonnabend and Whiteley 2011 pp 11-12). He lived in Via Margutta near Piazza di Spagna from 1627 moving in 1650 nearby to Via del Babuino and left the city via the nearby Porta del Popolo to 'wander up the Tiber to draw in the area of the Ponte Molle'; he also made excursions to the Campagna and Tivoli. The drawings he made of buildings and trees served as motifs for his paintings and he kept them in 'carefully ordered albums.' In Claude's 'Pastoral Landscape with the Ponte Molle', 1645 although 'it has the appearance of being a view of a real place' and 'the Ponte Molle is accurately represented' actually 'In the manner of composition which was habitual to Claude, he has formed the view by placing together a number of motifs to create a poetic capriccio which has 
no claims to topographical accuracy.' (Sonnabend and Whiteley 2011 p. $15 ;$ p. 36).

Claude frequently depicts large pine trees in his oil paintings including his 'Landscape with Narcissus and Echo' which he painted in 1644 for an unknown English patron. ${ }^{4}$ This painting, which depicts a large pine tree to the left overhanging and shading the pool which reflects Narcissus, was purchased by Sir George Beaumont in 1790 and donated by him to the National Gallery in 1828. David Blayney Brown considers this 'strikingly picturesque umbrageous' landscape to be indicative of the 'Picturesque sensibilities he was beginning to develop alongside' Uvedale Price and Richard Payne Knight in the 1790s (National Gallery 1988; Watkins and Cowell 2012).

Alexander Cozens (1717-1786) stayed in Rome 1746-9 and knew the French landscape artist Claude-Joseph Vernet who 'worked within the tradition of Claudian draughtsmanship' (Sloan 1986 p. 11; Kelly 2014, p. 45). Kokkonen ( 2014 p. 63 ) points out that from the 1720 s through to the 1750 s there was a tradition for students at the French Academy in Rome (established in 1666) to be taken on 'plein-air sketching trips' where they learnt how to compose directly from the landscape. On his return to England Alexander Cozens taught at Eton 1760-75 and in London and became a well-known teacher whose pupils over many years included George Beaumont, William Beckford and the children of George III. (Sloan 1986, p. 49). Oppe (p. 96) notes that 'Cozens had already shown close observation of trees, with their growth and their foliage when he was sketching at Rome' and in 1771 he published The Shape, Skeleton and Foliage of Thirty-two Species of Trees for the Use of Painting and Drawing, which was reissued in 1786 . Cozens recounted that while at Rome in the summer he went out every morning to sketch and outline

\footnotetext{
${ }^{4}$ Claude Lorrain 'Landscape with Narcissus and Echo' National Gallery. For image see: http://www.nationalgallery.org.uk/paintings/claude-landscape-with-narcissus-and-echo
} 
landscape from life and would then working up his drawings in the afternoon.

Many of these drawings are found in an album of c 1746 now at the British Museum. They have a remarkable history. A note which was once on the cover of the album states: 'Alexander Cozens, in London, Author of these Drawings, lost them \& many more, in Germany by their dropping from his Saddle when he was riding in his way from Rome to England, in the year 1746. / John Cozens his Son being at Florence in the year 1776 purchaced them. / When he arrived at London in the year 1779 he delivered the Drawings to his Father.' (BM) One of the drawings at the British Museum (Plate 5 BM 867,1012.14 c 1746 Pen and black ink) depicts a view of a road between walls with a distant view of St Peter's and Rome. On the left is a characteristic stone pine tree rising high above the other vegetation with irregular jutting stubs of branches below the umbrella shaped canopy. Another pen and ink drawing from the album (Plate 6 BM 1867,1012.24 c 1746) shows centrally the contrasting profiles of a stone pine and a cypress which partly block out the outline of the Villa Rufinella at Frascati behind.

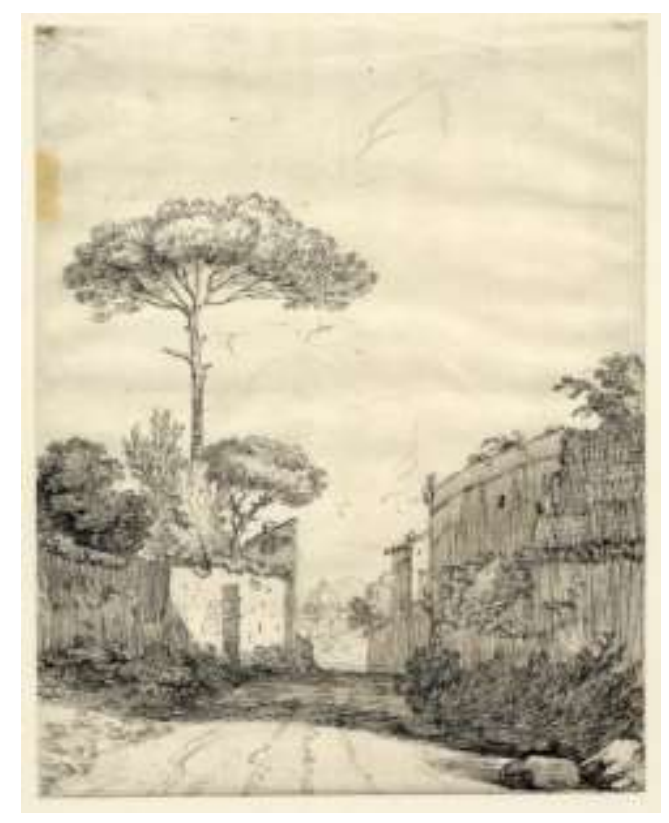

Plate 5 Alexander Cozens c 1746, British Museum. 


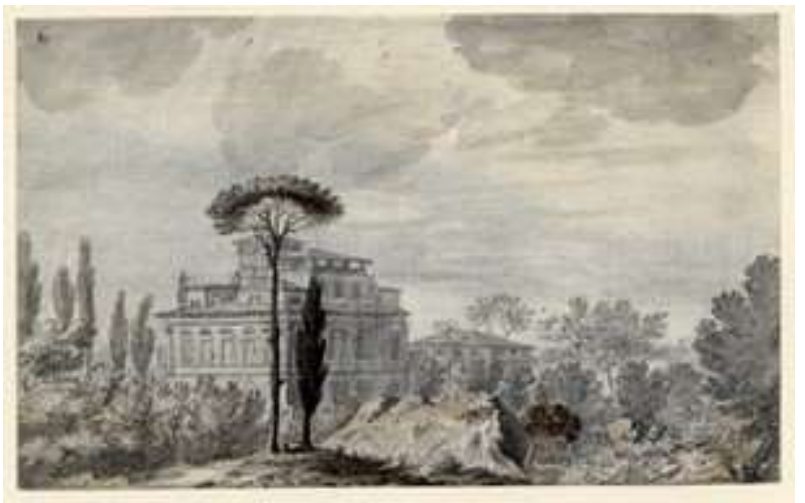

Plate 6 Alexander Cozens Villa Rufinella at Frascati c 1746, British Museum.

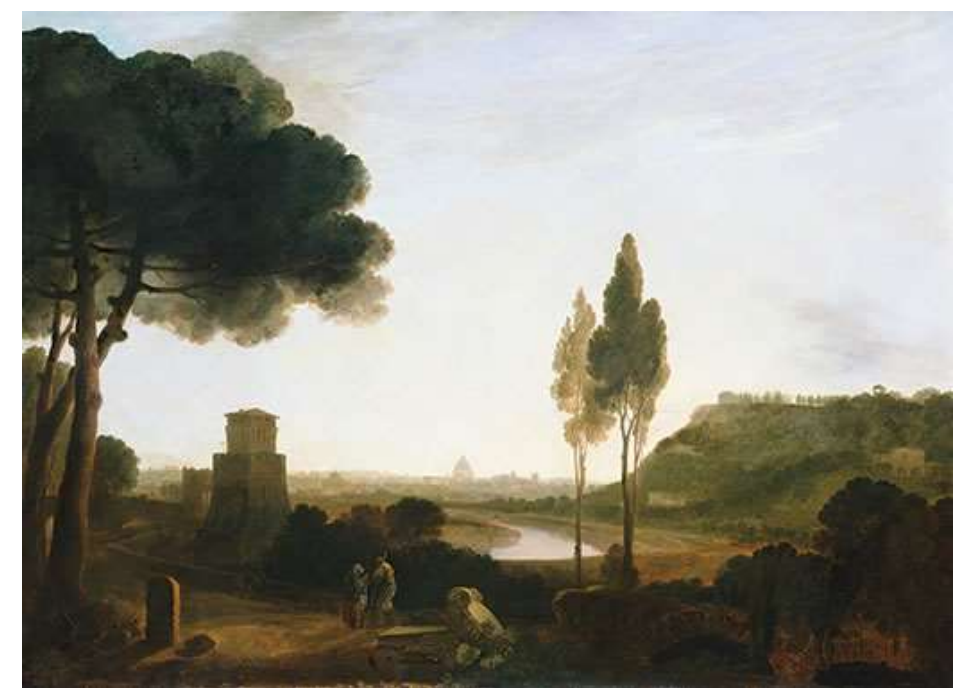

Plate 7 Richard Wilson 'Rome from the Ponte Molle 1754' (National Museum Wales)

The British artist Richard Wilson (1714-1782) was also influenced by Claude-Joseph Vernet, in 1752, and this encouraged him to paint landscapes (Kokkonen, 2014, p. 53; Barrell, 2014). In 'Rome from the Ponte Molle 1754' (Plate 7) Wilson 'plotted the features of the landscape with remarkable precision' (Postle and Simon, 2014, p 218) and the trunks, branches and foliage of the two large stone pines to the left are very clearly depicted. Brinsley Ford (1951, p. 27) found no direct 
relationship between Wilson's drawings from nature and his finished paintings and while stone pines were prominent in many of his paintings found 'not a single instance' when a drawn tree had been used as a model for a tree in a painting. He thought that Wilson may have become so 'familiar with the forms of nature to dispense with detailed working drawings' or 'varied the shapes of trees and branches to suit the requirements of the composition.'

Alexander Cozens's son John Robert Cozens set off on his first continental tour in 1776-79 with Richard Payne Knight staying in Rome and meeting many British artists. He visited Rome again in 1782-3 with William Beckford and met a wide circle of artists and patrons including Sir George Beaumont, 'with whom he appears to have sketched during 1783' (Sloan 2004). Many of his drawings show characteristic Roman trees, and like his father, he was fascinated by the contrast between the thin and spindly Roman cypresses and the bold clumps of the pines. His watercolour of Rome from the Villa Mellini (Plate 8 BM 1878, 1228.9) shows the slopes of Monte Mario, with a stone-pine and cypresses to the left and the city to the right. One of the watercolours commissioned by William Beckford is a view (c 1780) of St Peter's from the Villa Borghese. ${ }^{5}$ The Borghese gardens were established in 1606 and by the eighteenth century had gained a deer park. Here the pines dominate the watercolour and their lower branches have been cut back irregularly and are silhouetted against a setting sun with St Peter's in the distance with deer in the park below the pine trees.

\footnotetext{
${ }^{5}$ The University of Manchester. The Whitworth. For image see http://gallerysearch.ds.man.ac.uk/Detail/3176
} 


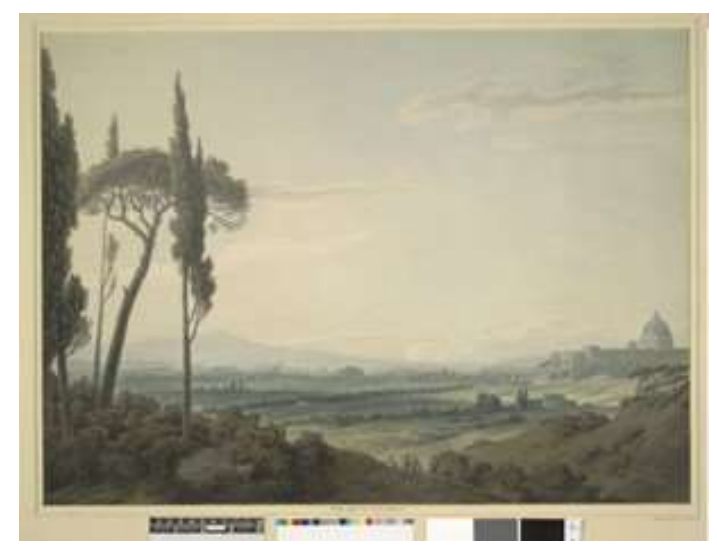

Plate 8 John Robert Cozens c. 1780 Rome from the Villa Mellini (British Museum)

After the Napoleonic wars the number of artists visiting Rome increased dramatically. Many of James Hakewell's views of Rome include stone pine trees, and he made studies of named pines such as the Colonna Pine in the Quirinal Gardens where according to the English traveller Charlotte Easton the 'massive fragments of an immense pediment of Parian marble... repose on the soft green turf, overshadowed by an ancient pine tree. It was just such a combination that a painter would have wished. It was more than picturesque.' (Cubberley and Herrmann 1992 p. 197). J.M.W. Turner made 'a careful record of the topography' and some 'detailed studies of the stone pine trees characteristic of the region' (Moorby 2015) as in 'Stone Pines on Monte Mario, with a View of Rome from near the Villa Mellini'(Tate Turner Bequest CLXXXIX 1819). ${ }^{6}$ And as we have seen, enthusiastic and skilled amateur artists such as Sir George Beaumont celebrated the pines as emblematic memorials of Roman landscape history.

Edward Lear was based in Rome 1837-1841 and made many sketches from which he made lithographs and published in 1841 as 'Views in Rome and its Environs Drawn from Nature and on Stone'. He celebrates the pines of Rome features which contrast with the surrounding landscapes. On the title page he shows the 'picturesque remnant' of the Castle of

\footnotetext{
${ }^{6}$ Tate Britain. For image see: http://www.tate.org.uk/art/artworks/turner-stone-pineson-monte-mario-with-a-view-of-rome-from-near-the-villa-mellini-d16337
} 
Ostia at the mouth of the Tiber which 'with its two pines adjoining, are a conspicuous object in the dreary Campagna' which surrounds the Campagna (Plate 9). His view of Frascati from Villa Mondragone is dominated by 'groups of the beautiful pines of Italy' beneath which can be seen 'the wide Campagna, stretching to the blue sea.' (Plate 10)

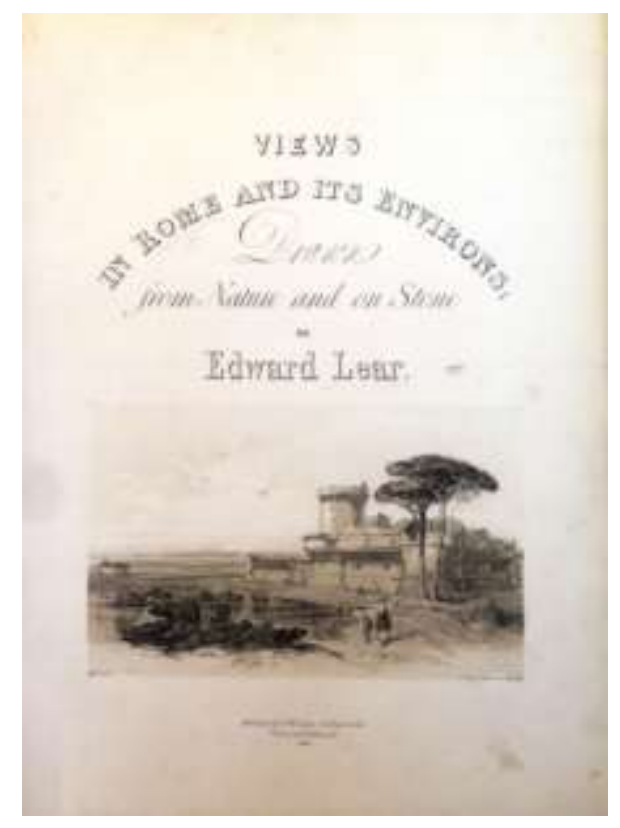

Plate 9 Edward Lear 1841 Views in Rome and its Environs Drawn from Nature and on Stone, London. Title Page

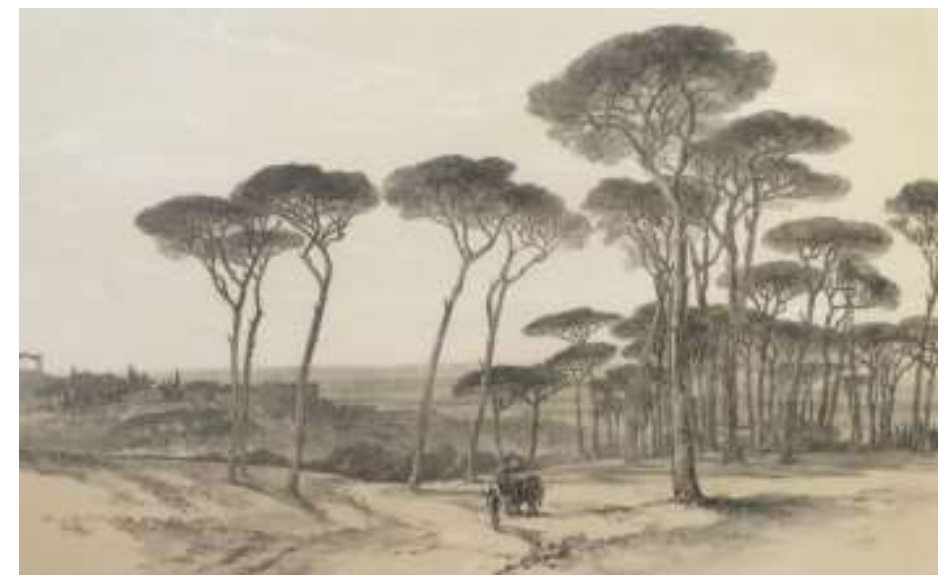

Plate 10 Edward Lear 1841 Views in Rome and its Environs Drawn from Nature and on Stone, London. View of Frascati from Villa Mondragone By the early nineteenth century the pines of Rome were a characteristic emblem of views of Rome. Claude's drawings and paintings had an 
enormous influence on following artists such as Richard Wilson and Alexander and Robert Cozens. Through these artists, and their pupils, amateur artists and visitors to Rome tried to understand the city from viewpoints in which ancient buildings such as the Pantheon and modern ones such as St Peter's were framed by pines and outside Rome, the Campagna and distant views of the sea were viewed beneath a canopy of shady pines.

\section{Ligurian Pines}

But what of pine trees and woods of northern Italy, which many travellers experienced on their way to Rome? Pines were very common along the Ligurian coast of northwest Italy and many English travellers and visitors depicted them, including Edward Lear, later to live permanently at San Remo, whose watercolour of the Ligurian coast at Porto Venere May 13 1860 (Plate 11) shows pines growing on the cliffs with the coast of eastern Liguria in the distance.

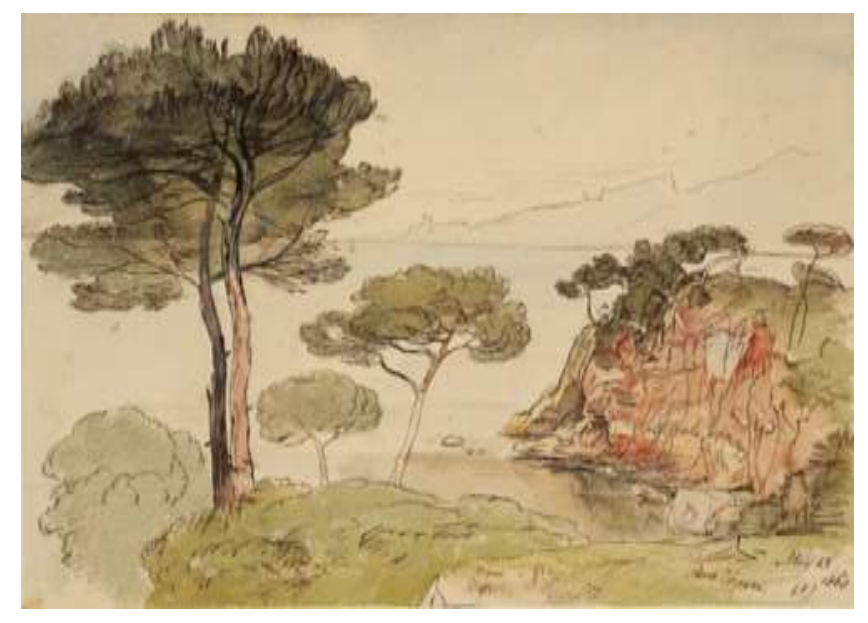

Plate 11 Edward Lear Porto Venere May 131860 Tate Britain

John Ruskin visited Sestri Levante in Liguria twice in the 1840s. The peninsula of Sestri Levante is a promontory of slate rock characterised by Mediterranean vegetation and with steep cliffs on its western part. On Ruskin's first visit (4 November 1840) he managed to climb 'the woody 
promontory tufted with Italian pine, that overhangs the village.' Above the surging sea was 'a group of dark Italian pine and evergreen oak.' (Evans and Whitehouse 1956 p. 102-3). Five years later, again at Sestri, he told his father 'Such a lovely place you never saw...' and celebrated 'the motion today of the flaky, interlaced white clouds through the stone pines as they rose against the blue, and the heavenly sunset ....' $\mathrm{He}$ wrote that 'I have been working all day like a horse, and have got a most valuable study of a stone pine - rock to sit on - under the shade of an ilex - no wind.... Air all scented by the pines \& wild flowers' (30 April Sestri 1845 (Sabrini 1972 p. 46). The next day 1 May 'the sound of the church bells all over the hills coming through the branches of the pines as I sat drawing.... I have got a beautiful study, and leave tomorrow morning for Spezia.' (p. 47).

Ruskin presented the drawing to the Ruskin Drawing School (University of Oxford) and catalogued it in 1870 as 'Pine, for Poseidon' in the Educational series in the "Catalogue of Examples" (Plate 12). He entitled it 'Study of trunks of stone-pine at Sestri, in the Gulf of Genoa. Pencil, secured with pen outline, and a slight wash of sepia. It is a good way of studying trees hastily' and he told his father that when he went to Italy in 1845 he had 'a new perception of the meaning of the words drawing and chiaroscuro' and that his 'first attempts with my new perception were those of the stone pines at Sestri, now in your bedroom'. Ruskin emphasised the classical importance of the stone pine in interpreting his drawing. He thought that the stone pine was particularly related in the 'Greek mind' with the sea and ships and that 'the true pine, whose double leaves give it the epithet $\delta ı \lambda \lambda \dot{\theta} \theta \rho \xi$, grows continually by the sea-shore, and is properly the one sacred to Poseidon.' He argued that his drawing of Italian pines 'will give you some idea of the mingled grace and strength of the tree, where it grows on crag, and is tried by storms, as among the Greek islands.' (Ashmolean Museum 
http://ruskin.ashmolean.org/collection/8979/object/13832; Cosgrove 2000)

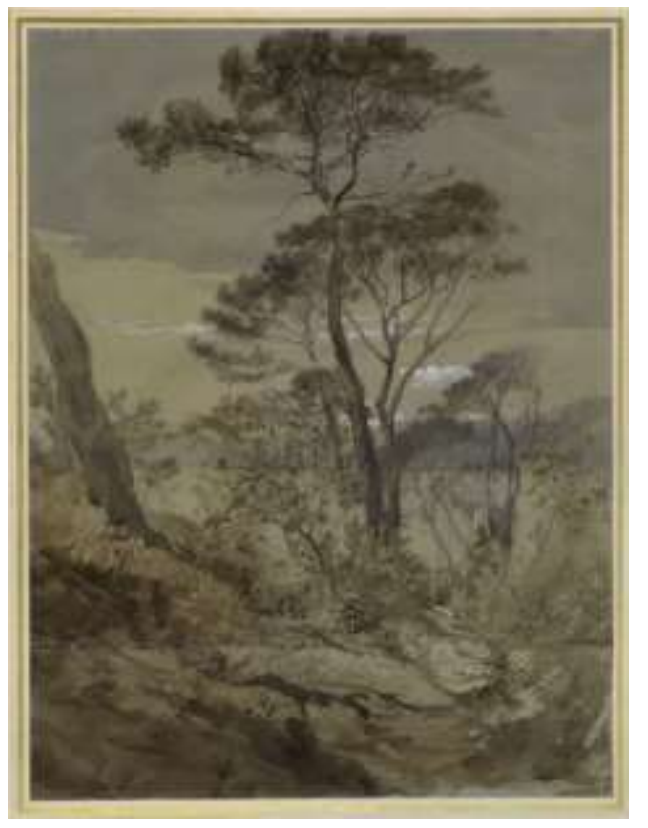

Plate 12 John Ruskin 30 April 1845 Stone Pines at Sestri, Gulf of Genoa Ashmolean Museum

While English visitors and artists celebrated the tree's classical connotations and picturesque possibilities, there was a lively debate among local landowners about the value and use of the pines. Some wanted to convert the large areas of pine woodland growing along the coast into more profitable vineyards, orchards or olive groves. In 1802, for example, Giovan Battista Pini, a member of the Istituto Nazionale of the Ligurian Republic which encouraged improvement of culture and knowledge argued that the coast of Zoagli had many pines, which were used to build small boats but grew very slowly and were uneconomic. He thought that the pines should be replaced with vineyards and fruit trees and that an additional fee should be imposed on those who had pines on fertile land located less than a mile from the coast (Letter 7, Giovan Battista Pini to G. De Ambrosis 25 February 1802, from Gotta 1990).

Other commentators considered pines important for the establishment of the woodland on infertile sites. Gian Maria Piccone (1722-1832) a priest 
and scholar with interests in agriculture and forestry, wrote an essay on how to re-establish and cultivate the woodland in the Genoese territory and celebrated the importance of pine trees (Piccone, 1796). The pines, Piccone argued, grew particularly well on bare and infertile slopes as their roots penetrated the cracks in the rocks. He thought that pine woods should be established along the coastal plains such as in Lavagna at the mouth of the Entella River, between Chiavari and Sestri Levante, and in Albenga in western Liguria. The practice of planting pine woods in flat coastal areas was particularly common in Tuscany, along the Tyrrhenian coast south of La Spezia. Since the eighteenth century the Grand Duchy of Tuscany and the Republic of Lucca promoted plantations following the drainage of coastal marshlands. The more frugal Maritime pine (Pinus pinaster) was usually planted next to the sea to protect the stone pine (Pinus pinea), which grew further inland and bore pine nuts (Serafini 2000). The bark of stone pines was ground in the mills of the Acquaviva Valley of Portofino to extract tannin used to paint the fishing nets to make them less visible to the fish (Piana 2011).

Piccone recommended that 'Pini marittimi' should be planted in Liguria but the distinction between different species of pine was not clear cut. In 1822 an assessment of woodland condition, known as Denunce $e$ consegne dei boschi was produced for each municipality. This lists every property and provides details about tree species and how woodland was used (Cevasco 2007). In the Consegne dei Boschi document, a distinction is often made between 'domestic' and 'wild' pines. It is likely that the 'pino domestico' was the stone pine as this is the name used in current Italian to indicate it. The definition of 'pino selvatico' (wild pine) probably referred to two species still common in the area: the Aleppo pine (Pinus halepensis) is a native Mediterranean species with wide distribution in Liguria, while the Maritime pine (Pinus pinaster) has been planted on the mountains around Genoa especially since 1870 (Moreno et al. 1993). In the twentieth century maritime pines took advantage of the abandonment 
of fields and terraces to spread along the coast and on mountains (Martini 1996). It is likely that the pines drawn by Ruskin were either Aleppo or Maritime pines, which form extensive wooded tracts along the Ligurian coast, rather than stone pines.

Amateur topographical artists William Thomas Horner Fox-Strangways (1795-1865) and Elizabeth Fanshawe (1779-1856) visited Liguria respectively in 1821 and 1829-31 (Piana et al 2012; Piana 2015). Sestri Levante seen from the north is the object of two views by William Strangways (Plate 13) and Elizabeth Fanshawe (Plate 14), where the outline of the Peninsula, with the contrast between the woodland and the village, the typical houses, the boats and the beach show a quintessentially Ligurian landscape. The views are very different in style but are both valuable documents for landscape history as they underline some of the main features of this landscape.

In the Fanshawe drawing there is a tree standing on the ridge, which can be identified as stone pine (Pinus pinea) due to its characteristic umbrella shape. Contemporary documents provide evidence of the historical presence of pine trees in the Peninsula of Sestri, which is locally called L'Isola. A contemporary manuscript map (Minuta di Campagna) produced by the Sardinian Kingdom between 1816 and 1827 shows a clear separation between the cultivated area and the woodland and the rocks of the western part of the peninsula (Plate 15). The map has no key, but contemporary documents and fieldwork help with the interpetation of the symbols. The dark green lines spread across the eastern part of the peninsula are terraces sustained by dry stone walls; these are also sketched by Strangways. To the west the map symbols indicate at least two types of vegetation. Strangways depicts a group of high, thin trees along the ridge and some bushy, rounded plants close to the villa in the foreground. In Fanshawe, the tree is located in the area south of the locality called Batteria and this suggests that the symbols concentrated there on the map represent pines. 


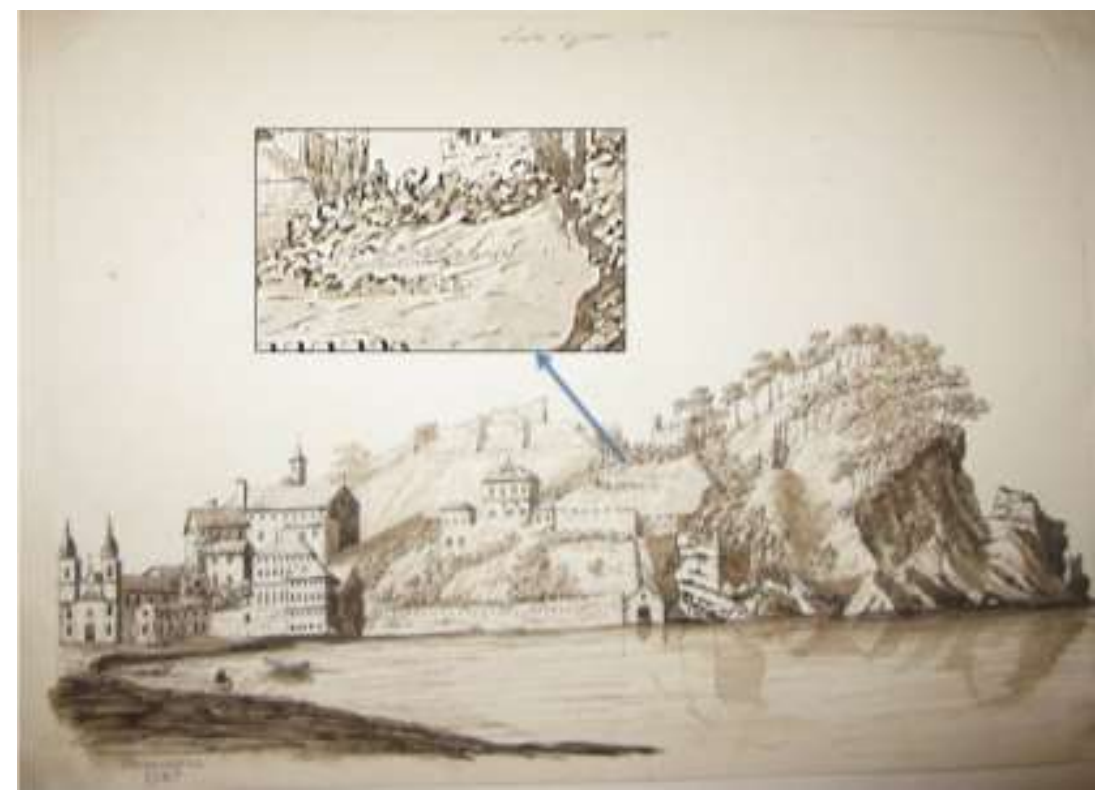

Plate 13 William Strangways 'from above Chiavari on the road to Genoa' / 'V Sestri and its bay' / 'VV Chiavari in two parts' (1821), wash drawing on paper $(265 \times 376 \mathrm{~mm})$ (with detail of terraces). Viewed from the North

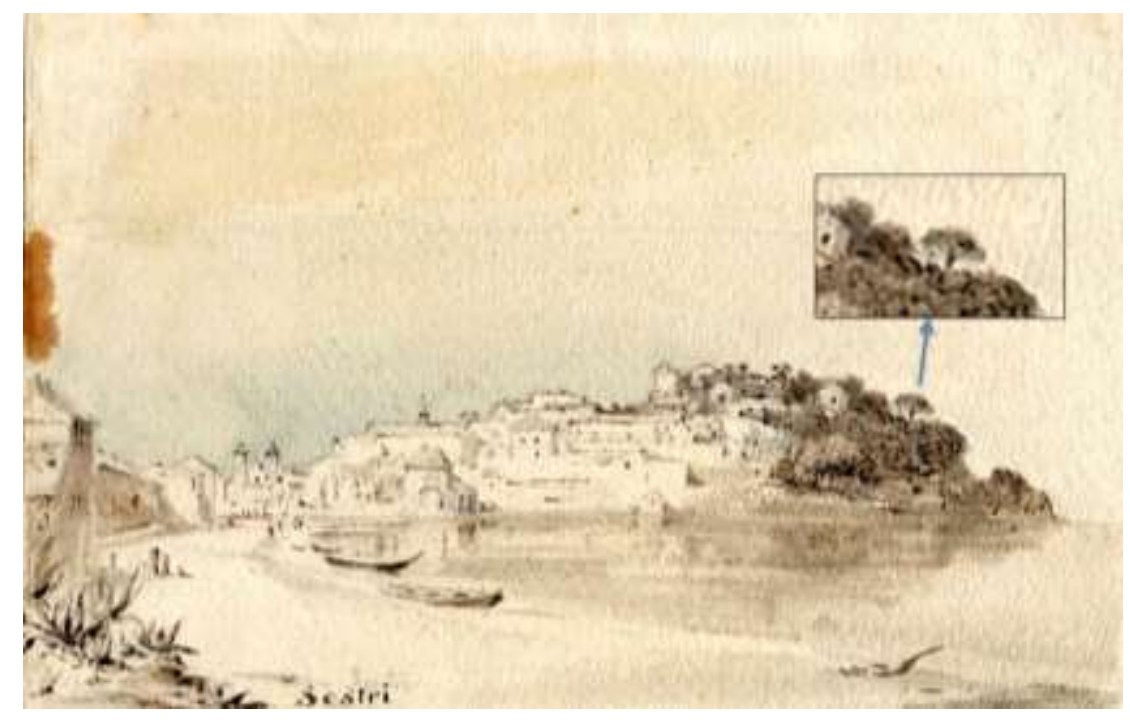

Plate 14 Elizabeth Fanshawe, 'Sestri' (19 ${ }^{\text {th }}$ November 1829 or April 1830), wash drawing (130 $\times 210 \mathrm{~mm})$ (with detail of stone pine). From the North. 


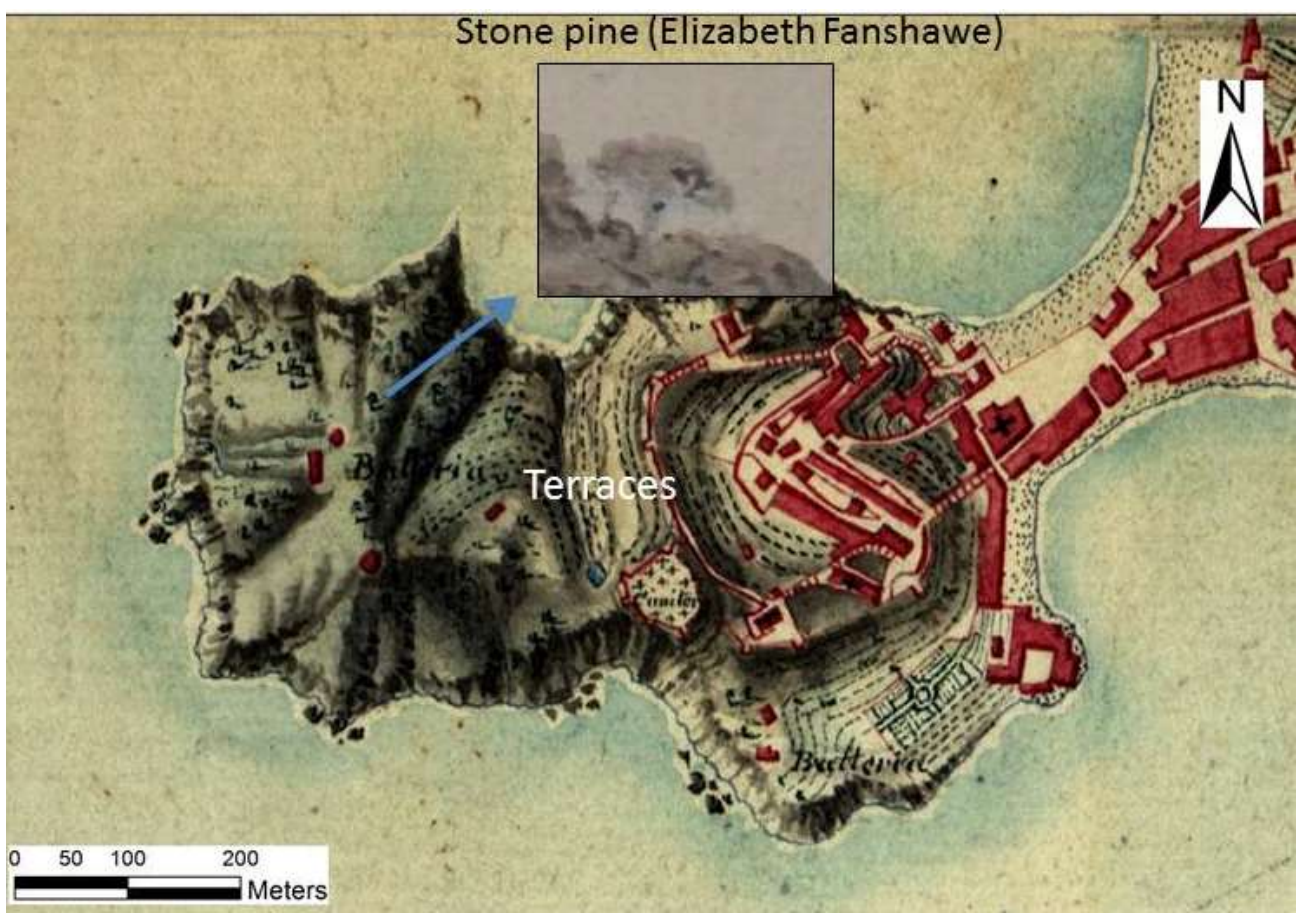

Plate 15 Riviera di Levante alla Quarta della Scala di Savoia (1816-27) Minuta di Campagna sc 1:9450, sheet 60 Archivio Storico IGM

This interpretation is backed up by the description of the agricultural landscape of the peninsula made by the priest of Sestri, Don Gaetano Questa in his report written in 1799 for the Inchiesta dell'Istituto Nazionale, which was a survey on the socio-economic conditions of parishes and municipalities of Liguria:

Quest'isola era del circuito in mare di circa un miglio, tutt'insieme aveva ed ha terreno da tutte le parti quale é occupato da vigneti, da luoghi ad uso di seminativi, altro ad uso di aranci e limoni, e nelle parti piú sassose, come é verso Ponente, da pini ('this island was surrounded by the sea for a mile and has a terrain occupied by vines, other places used as arable, other oranges and in the pebbly areas it is occupied by pines, as in its western part.' $)^{7}$

Further evidence is provided by the 1822 Denunce e consegne dei boschi which shows that much of the Sestri peninsula owned by the Marquis

\footnotetext{
${ }^{7}$ ASG Repubblica Ligure 610, Inchiesta Istituto Nazionale, Giurisdizione Gromolo e Vara, doc. Sestri Levante (7 March 1799).
} 
Giuseppe Piuma consisted of pine woodland, mainly selvatici (wild pine), sessile oaks, holm oaks and bushes of different species. Branches cut from the pines together with Mediterranean shrubs ('arbusti di specie diverse') were used for the production of concime (manure). Only 30 trees were large enough to be used for the production of boards. At the end of this report, Giuseppe Piuma added a series of suggestions about the use of pine trees in the area. He argued that the pines needed to be regularly trimmed and the branches were cut to obtain poles to support the vines and the fruit trees. Piuma complained about the low fertility of the soil which did not allow tagli regolari (regular felling) since the trees grew too slowly. ${ }^{8}$

From the records of the Societá Economica we learn that in 1797 Andrea Migone summarised a list of actions designed to improve Ligurian agriculture, including planting new pines for 'fine timber' (Casaretto 2001, p. 31) which were also used in the Tigullio to build small boats (Gotta 1990 , p. 87). In the traditional agriculture of the coast, even the most unproductive areas were exploited, and this would explain the frequent reports of the use of pine branches and shrubby vegetation used as fertilizer ('concime') for the vineyard. The importance of pine needles is not limited to the Mediterranean countries: pine and spruce needles were used in the Swiss Alps as litter for cows (Gimmi and Burgi 2007).

In Zoagli, between Chiavari and Rapallo, William Strangways depicted the landscape of the flat Entella Valley viewed from the hill of Le Grazie with two pines in the foreground (Plate 16). Contemporary documents state that pines were planted in the driest and most unfertile areas where, as in the case of a pine wood in Chiavari, the slow growing of the trees (50 years) did not allow a profitable exploitation of the trees for timber or for boat building. ${ }^{9}$ In addition to the infertility of the soil, grazing animals

\footnotetext{
${ }^{8}$ ASG Prefettura Sarda 207, Denunce e consegne dei boschi, mandamento di Sestri Levante, 95 (13 May 1822).

${ }^{9}$ ASG Prefettura Sarda 206, Denunce e consegne dei boschi, mandamento di Chiavari, 84 (29 May 1822)
} 
prevented tree growth as shepherds let their sheep graze in the pine plantations, although this was prohibited. ${ }^{10}$ As in Sestri Levante, pine branches in Chiavari and Zoagli were used as poles to support the vines. The trees depicted by Strangways are probably maritime pine (Pinus pinaster), which is still particularly common on the coastal hills of the Tigullio Gulf. The trees appear to be stripped, as if the lower branches were cut, possibly to be used as poles for the vines and as fertilizer. The contemporary Minuta shows the distribution of land-use in the area of Le Grazie (Plate 17). The gentler fields, particularly along the main road, are terraced and cultivated, while the pines are spread across the most infertile areas such as the ridge above the church of Nostra Signora delle Grazie or the edge of the cliff below the road.

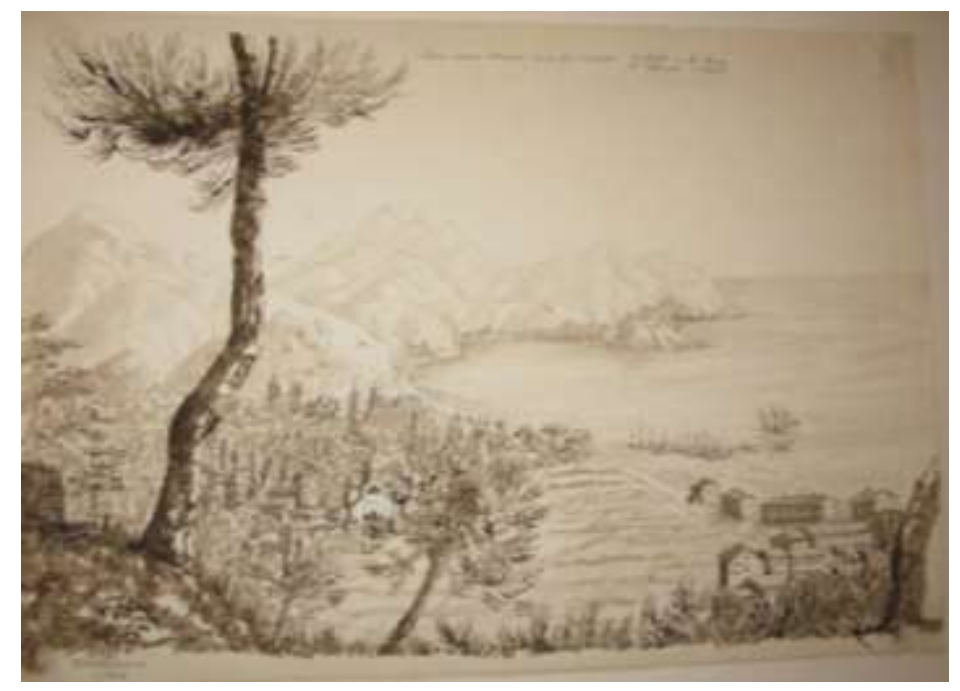

Plate 16 William Strangways 1 'from above Chiavari on the road to Genoa' / 'V Sestri and its bay' / 'VV Chiavari in two parts'(1821), wash drawing on paper $(265 \times 376 \mathrm{~mm})$.

${ }^{10}$ ASG Prefettura Sarda 206, Denunce e consegne dei boschi, mandamento di Chiavari, 29 (25 May 1822) 


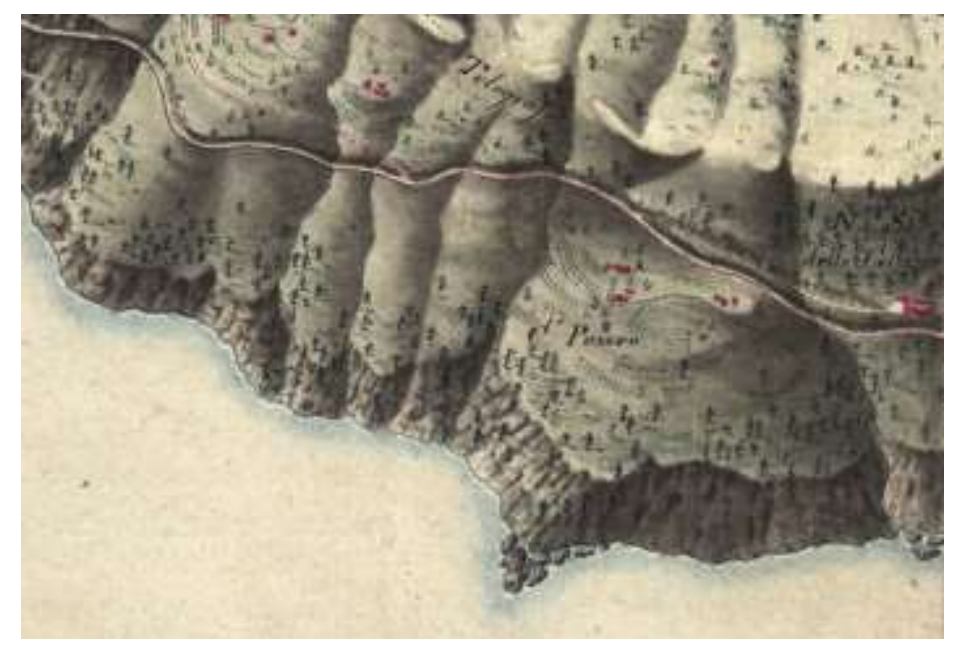

Plate 17 Riviera di Levante alla Quarta della Scala di Savoia (1816-27) Archivio Storico IGM, Minuta di Campagna sc 1:9450, sheet 61.

The arrival of the railway in the nineteenth century brought a rapid expansion of tourism to the Ligurian coast and many British visitors. Alice Comyns Carr (1878, pp. 92-3) celebrated the coast near Porto Fino as 'a region of stone pines' where the 'goodly trees rise up from out the soft earth, and their straight stems, with the curiously curved bark, stand tall and erect.... and can yet stretch their branches far out over the waves, so that the most barren edge of land by them is made beautiful and softened.' The artist and writer Walter Tyndale (1914, p. 90) stayed at Sestri in 1913 and was delighted by the pine trees on the Sestri peninsula. He noted that 'The Marchese Piuma kindly allows (when he is not in residence) the visitors to Sestri Levante to make use of his grounds'. This is 'a great boon' to artists who wish to make studies of 'a semi-wild and picturesque Italian garden'. Away from the gardens of the villa 'the ilex groves, and the noble clusters of pines have been allowed to grow as Nature pleases.' This understanding of pines allowed to grow wild and 'as Nature pleases' is very different from the planted, cultivated and pruned pines described by Italian improving landowners in the early nineteenth century. 


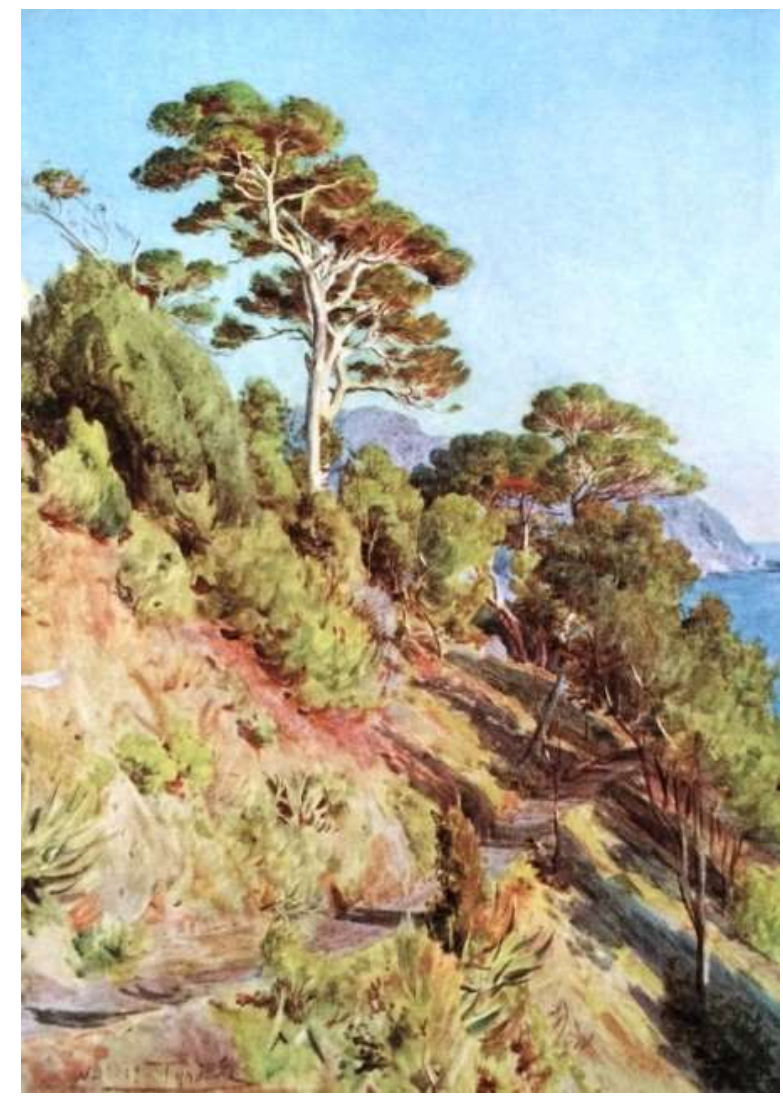

Plate 18 Walter Tyndale 1913. In the Villa Piuma, Sestri Levante

\section{Ravenna Pine Wood}

For a British view of managed pine woods we turn to the 'most celebrated forest' of stone pines in Italy, the Pineta di Ravenna 'in which Dante, according to tradition, composed the Divine Commedia whilst he walked amidst its glades' (Elwes and Henry 1906-13 5 pp 1120-2). Lord Byron lived for much of the period 1819-21 in Ravenna while Sir George Beaumont visited Rome, and part of the same burst of British visitors to Italy. Friends reported that Byron regularly went riding in the pine woods after writing sections of his poem Don Juan during the day. He went two hours before sunset with visiting friends such as Shelley for exercise and shooting practice in the woods. Sometimes he rode out with Teresa Guiccioli his mistress and 'plunged far into that lovely forest, and stayed there for hours to breathe in its wholesome fragrances. They dismounted and seated themselves beneath the umbrella pines, inhaling even more 
deeply the aromas of the resinous trees, which swayed in cool breezes from the sea.' (Guiccioli, 2002, p. 153; MacCarthy, 2002). When in the pine woods he recollected the stories of Boccaccio set in Ravenna and wrote

'Sweet hour of twilight! - in the solitude

Of the pine forest, and the silent shore

Which bounds Ravenna's immemorial wood...' (Don Juan Canto III, st 105)

Byron relished the woods themselves and their literary links with Dante and Boccaccio.

One of the earliest paintings of the Ravenna pine woods is Botticelli's panel Nastagio degli Onesti (1483) now in the Prado Madrid (Plate 19). This depicts the story of Nastagio from Boccaccio's Decameron, a young man from Ravenna who was rejected by a woman and shows him seeing a woman attacked by dogs and pursued by a man on a horse. The stone pine trees are very clearly depicted by Botticelli who shows the characteristic stems and the stumps of the cut limbs below the canopy. It is unlikely that Byron would have seen this painting as Botticelli had become deeply unfashionable in the seventeenth and eighteenth centuries and remained so until after 1850 when 'a taste for Botticelli's art began to percolate down to a popular level' and became popular with the PreRaphaelites and later critics such as Walter Pater. Most of his works remained 'hidden away in Tuscan churches and private houses, unseen by the tourist and unmentioned by guidebooks.' (Ettlinger 1976, p. 204) This painting which had been commissioned by Antonio Pucci in 1483 for a wedding chest for his son remained in the Pucci Collection in Florence until 1868. 


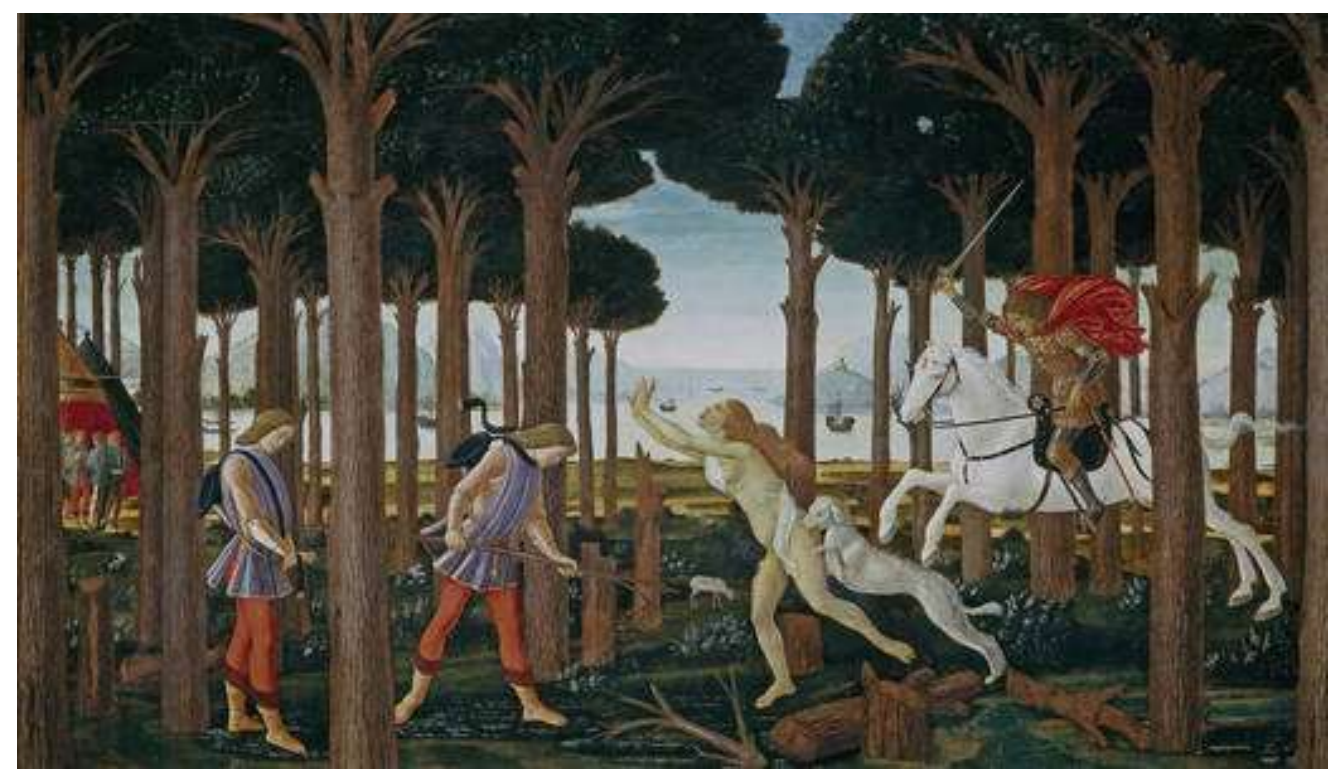

(Plate 19) Sandro Botticelli 1483 Nastagio degli Onesti, painted panel Prado Madrid

Byron's visit added a potent additional layer of meaning to the Ravenna pinewoods for British visitors. Edward Lear made several drawings and paintings of the pines ${ }^{11}$ and John Addington Symonds writing in 1879 emphasised the literary connections: here Dante 'would spend whole days alone among the forest glades... meditating cantos of his poem', and Lord Byron who lived in Ravenna for a couple of years 'used to haunt its wilderness, riding alone or in the company of friends in the pine woods.' Symonds notes that the inscription on the entrance to the house Byron lived in alluded to the forest 'as one of the objects which principally attracted the poet to the neighbourhood of Ravenna' but points out that the main purpose was to visit his mistress the Countess Guiccioli.

The wood was 'about 16 miles in length and a mile in width; and in 1866 covered about 10,500 acres...' By the end of the nineteenth century the timber was no longer used for shipbuilding, but the tree remained important for its edible nuts (Elwes and Henry 1906-13 Vol V pp. 11202). Edward Lear painted the Ravenna pines in 1882 and there is a

\footnotetext{
${ }^{11}$ See for example http://www.bonhams.com/auctions/22589/lot/71/
} 
photograph of the woods in c 1883 in the travel album of Prince Leopold with the trees showing their characteristic form and fairly widely spaced (Plate 20). When John Addington Symonds (1879) visited the wood he thought that it was 'hardly possible to imagine a more beautiful and impressive scene than that presented by these long alleys of imperial pines. They grow so thickly one behind another, that we might compare them to the pipes of a great organ, or the pillars of a Gothic church, or the basaltic columns of the Giant's Causeway.'

$\mathrm{He}$ is one of the few British visitors to describe the process of collecting the pine nuts in any detail. The trees were 'laden with the heavy cones' which were important for the local economy. He saw that 'Scores of peasants are quartered on the outskirts of the forest, whose business it is to scale the pines and rob them of their fruit at certain seasons of the year.' The cones were dried in the sun and the nuts were exported and the husks used as firewood. 'You may see the peasants, men, women, and boys, sorting them by millions, drying and sifting them upon the open spaces of the wood, and packing them in sacks to send abroad through Italy. 'Symonds pointed out that the harvesting of the pine cones was dangerous: the workers 'have to cut notches in the straight shafts, and having climbed, often to the height of eighty feet, to lean upon the branches, and detach the fir-cones with a pole - and this for every tree. Some lives, they say, are yearly lost in the business.' Symonds also celebrated the animals that thrived in the pine woods: lizards 'run about by myriads in the grass'; 'huge oxen haunt the wilderness'; 'a sullen canal... is alive with frogs, newts and snakes.' (pp. 236-7) 


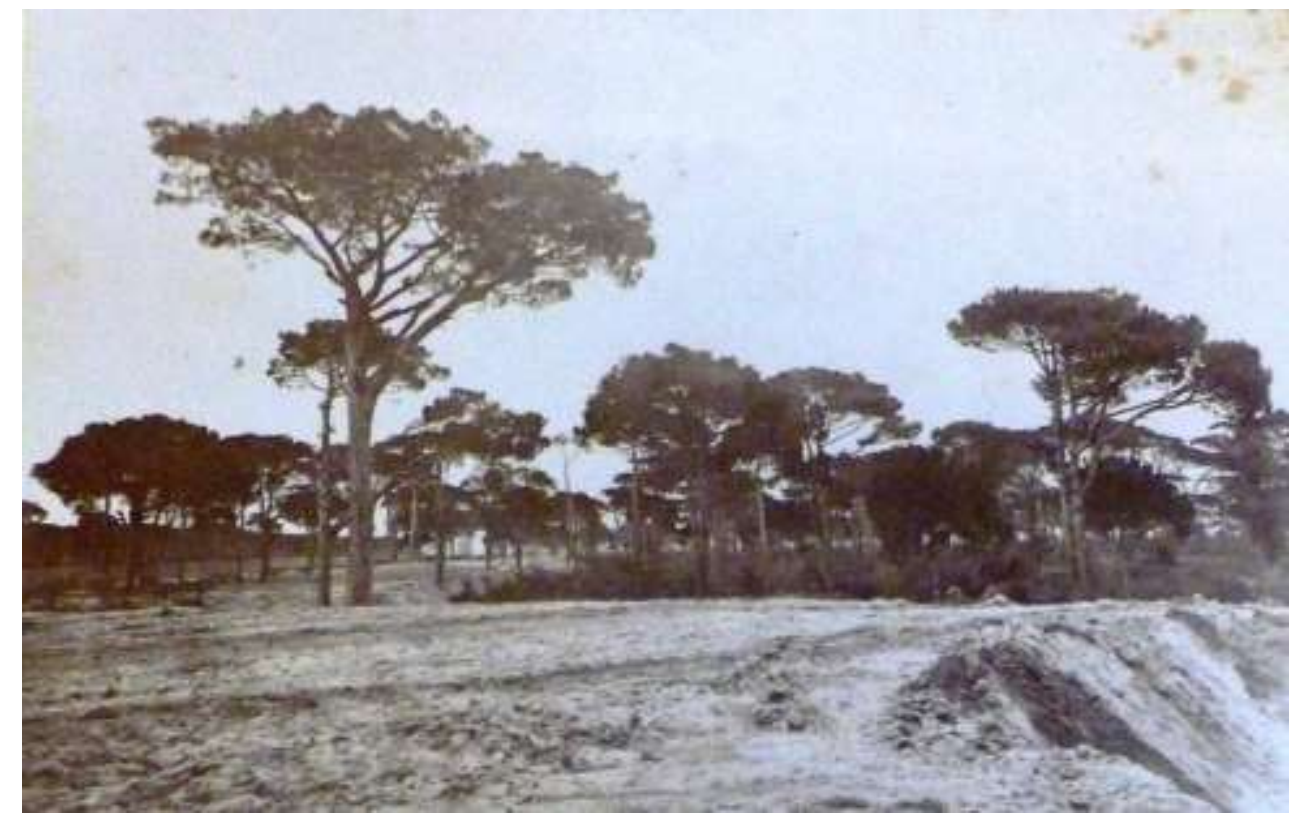

Plate 20 Topographical photographs associated with Prince Leopold (1853-1884), 1st Duke of Albany, undated, c.1884 Nottingham University MS317

\section{Conclusion}

Pine trees were a fundamental element of the classical Italian coastal landscape and they represented one of the most popular subjects in paintings and drawings of Italian landscapes by local and foreign artists. In addition to their use as ornamental trees in parks and villas, pines also constituted an important economic resource in both coastal and inland areas. This paper has examined a range of representations of pines, demonstrating the importance of topographical art for landscape history (Bonehill and Daniels 2009; Barrell 2013a, Barrell 2013b). Traditionally associated with cartography, topographic art can be an innovative way to investigate past landscapes not only for what the drawings represent, but also for meanings which reflect the interaction between the artist and the territory.

Trees were particularly important in British picturesque landscape representations and their accurate depiction reflected increasing interest in botany and the natural sciences by eighteenth-century artists. Many 
artists, such as Alexander Cozens, Richard Wilson and John Robert Cozens were strongly influenced by the landscapes of Claude Lorrain. The same attention to trees and pines in particular arises from contemporary writings by visitors in Italy and these document outsiders' views and understandings of the Italian pines. These were influenced by classical authors such as Theophrastus and Pliny, who first distinguished between different kinds of pines. Uncertainty about whether or not pines, and stone pines in particular, were native to Italy and on the distinction between the different species characterised nineteenth-century descriptions by both foreign and Italian commentators. Written reports by foreign visitors, such as John Addington Symonds's detailed description of the harvest in Ravenna (1879), offer crucial information on the traditional use of pines. In Liguria, estate papers often distinguish between 'wild' and 'domestic' pines, and the traditional use of the trees is described in detail. For the Eastern Riviera of Liguria the traditional uses of pine trees and the landscape history were reconstructed through the comparison of drawings with maps, contemporary records and descriptions by visitors. This example shows the benefits of the triangulation of the sources for reconstructing past landscapes and giving new insights into contemporary landscape management policies.

\section{Bibliography}

Agrimi, M., and Ciancio, O. 1994. Le pin pignon (Pinus pinea L.) (Larnaca).

Allevato, E., Buonincontri, M., Vairo, M., Pecci, A., Cau, M.A., Yoneda, C. M., De Simone, G.F., Aoyagi, M., Angelelli, C., Matsuyama, S., Takeuchi, K., Di Pasquale, G. 2012. Persistence of the cultural landscape in Campania (Southern Italy) before the AD 472 Vesuvius eruption: archaeoenvironmental data Journal of Archaeological Science 39 (2), pp. 399-406. 
Avery-Quash, Susanna and Sheldon, Julie 2011 Art for the Nation. The Eastlakes and the Victorian Art World (London).

Barrell, John 2013a Edward Pugh of Ruthin 1763-1813 'A Native Artist' (Cardiff).

Barrell, John London Review of Books 35, 18, 3 January 2013b pp 17-18. Barrell, John London Review of Books 36, 18, 25 September 2014 pp 36-7. Black, Jeremy 2003. Italy and the Grand Tour (New Haven and London). Brilli, Attilio 2006. Il viaggio in Italia. Storia di una grande tradizione culturale (Bologna).

Buzard, James 1993. The Beaten Track. European tourism, literature, and the way to 'culture' 1800-1918 (Oxford).

Casaretto, Francesco 2001. Annali di agricoltura nel Tigullio (Societa' Economica di Chiavari) (Unpublished work).

Cevasco, Roberta 2007. Memoria Verde, nuovi spazi per la Geografia (Reggio Emilia).

Comyns Carr, Alice 1878. North Italian Folk (London).

Cosgove, Denis, 2000. John Ruskin and the Geographical Imagination http://ruskin.ashmolean.org/collection/9006/9037/.

Cozens, Alexander 1771. The Shape, Skeleton and Foliage of Thirty-two Species of Trees for the Use of Painting and Drawing (London).

Cozens, John Robert 1789. Delineations of the General Character, Ramifications and Foliage of Forest Trees [Prints by Henry Pyne] (London).

Cubberley, Tony and Herrmann, Luke with Scott, Valerie 1992. Twilight of the Grand Tour. A catalogue of the drawings by James Hakewill in the British School at Rome Library (Rome). 
Elwes, Henry John and Henry, Augustine 1906-13 The Trees of Great Britain and Ireland (Edinburgh).

Ettlinger, L. D. and Helen S. 1976. Botticelli (London).

Evans, Joan and Whitehouse, John Howard (ed) 1956 The Diaries of John Ruskin 1835-1847 (Oxford).

Fady, B. 2012. Biogeography of neutral genes and recent evolutionary history of pines in the Mediterranean Basin Annals of Forest Science 69 (4), pp. $421-428$.

Ford, Brinsley 1951. The Drawings of Richard Wilson (London).

Knight, William (ed) 1896. The Poetical Works of William Wordsworth, Vol. VIII The Pine of Monte Mario at Rome, text with some notes (London) pp. 58-59.

Fenaroli, Luigi 1967. Gli alberi d'Italia (Milano).

Gilpin, William 1791. Remarks on Forest Scenery (London).

Gimmi, Urs and Burgi, Matthias (2007) 'Using oral history and forest management plans to reconstruct traditional non-timber forest uses in the Swiss Rhone Valley (Valais) since the late nineteenth century'. Environment and History 13: pp. 211-246.

Gotta, Rossella 1990. Il Tigullio nelle descrizioni di G. B. Pini (Genova). Guiccioli, Teresa Translated by Michael Rees, 2005 Lord Byron's life in Italy (Newark, Delaware).

Hawcroft, Francis W. 1971. Watercolours by John Robert Cozens (London).

Hooke, Della 2010. Trees in Anglo-Saxon England. (Woodbridge). Hort, Sir Arthur 1916, Theophrastus Enquiry into plants (London). 
Kokkonen, Lars 2014. "This so important a Crisis of my life": Wilson in Rome and the Vernet Effect' in Postle, Martin and Simon, Robin 2014. Richard Wilson and the Transformation of European Landscape Painting (New Haven) pp. 53-69.

Lear, Edward 1841. A Series of Twenty-Five Views in Rome and its Environs, Drawn from Nature, and on Stone (London).

Liversidge, Michael and Edwards, Catharine (eds) 1996. Imagining Rome. British Artists and Rome in the Nineteenth Century (London).

Loudon, John Claudius, 1854. Arboretum et Fruticetum Britannicum (Edinburgh).

MacCarthy, Fiona 2002. Byron Life and Legend (London).

Martínez, Felipe and Montero, Gregorio 2004. The Pinus pinea L. woodlands along the coast of South-western Spain: data for a new geobotanical interpretation Plant Ecology 175 1-18.

Martini, Enrico 1996. La vegetazione della Provincia di Genova (Genova). Moorby, Nicola 2015 'Stone Pines on Monte Mario, with a View of Rome from near the Villa Mellini 1819 by Joseph Mallord William Turner', catalogue entry, July 2009, in David Blayney Brown (ed.), J.M.W. Turner: Sketchbooks, Drawings and Watercolours, December 2012, https://www.tate.org.uk/art/research-publications/jmw-turner/josephmallord-william-turner-stone-pines-on-monte-mario-with-a-view-of-romefrom-near-the-r1132460, accessed 28 May 2015.

Moreno, Diego, Croce, G.F., Guido, Maria Angela and Montanari, Carlo 1993. 'Pine plantations on ancient grassland: Ecological changes in the Mediterranean mountains of Liguria, Italy, during the $19^{\text {th }}$ and $20^{\text {th }}$ Centuries.' In: Watkins, C. (Ed.) Ecological Effects of Afforestation. Studies in the History and Ecology of Afforestation in Western Europe (Wallingford), pp. 93-110. 
National Gallery, 1988. 'Noble and Patriotic' The Beaumont Gift 1828 (London).

Oppé, A. P. 1952. Alexander and John Robert Cozens (London).

Olsen, Christina 1992. 'Gross expenditure: Botticelli's Nastagio degli onesti panels' Art History, 15, 2 pp. 146-170.

Owen, Felicity and Brown, David Blayney 1988. Collector of Genius. A Life of Sir George Beaumont (New Haven and London).

Piana, Pietro 2011. La Valle dei Mulini dell'Acquaviva nel Parco Naturale Regionale di Portofino: Ricerce di Geografia Storica (Unpublished Master thesis, University of Genoa).

Piana, Pietro 2015. Topographical Art and Landscape History in CentralEastern Liguria (c. 1770-1840) (Unpublished PhD thesis, University of Nottingham).

Piana, Pietro, Balzaretti, Ross, Moreno, Diego and Watkins, Charles 2012. Topographical art and landscape history: Elizabeth Fanshawe (17791856 ) in early nineteenth-century Liguria Landscape History 33(2), 65-81 Piccone, Gian Maria 1796. Memoria sul ristabilimento e coltura de' boschi del Genovesato: breve istruzione sulla raccolta ed uso di alcune sostanze resinose della melesa e del pino (Genova).

Postle, Martin and Simon, Robin 2014. Richard Wilson and the Transformation of European Landscape Painting (New Haven).

Rackham, H. 1945. Pliny Natural History (London).

Sabrini, Harold I. (ed) 1972. Ruskin in Italy. Letters to his parents 1845 (Oxford).

Sadler, Thomas (ed) 1869. Diary, Reminiscences, and Correspondence of Henry Crabb Robinson Vol. III (London). 
Serafini, Antonella 2000. La Nascita delle Pinete (Pontedera).

Sloan, Kim 1986. Alexander and John Robert Cozens: the Poetry of Landscape (New Haven and London).

Sloan, Kim 2004. Cozens, John Robert (1752-1797), landscape watercolour painter, Oxford Dictionary of National Biography.

Sloan, Kim 2004. Cozens, Alexander (1717-1786), landscape painter, Oxford Dictionary of National Biography.

Sonnabend, Martin and Whiteley, John 2011. Claude Lorrain The Enchanted Landscape (Oxford).

Symonds, John Addington 1879. $2^{\text {nd }}$ ed Sketches in Italy and Greece (London).

Tyndale, Walter 1914. An Artist in the Riviera (London).

Watkins, Charles 2014. Trees, Woods and Forests. A Social and Cultural History. (London). 